\title{
VIRULENCE OF MYCOBACTERIUM JOHNEI IN EXPERIMENTALLY INFECTED CALVES
}

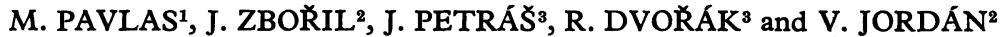 \\ Veterinary Research Institute, $62132 \mathrm{Brno}^{1}$, Bioveta, 68323 Ivanovice na Hané2, Institute for \\ State Control of Veterinary Biologicals and Medicaments, $62100 \mathrm{Brno}^{3}$
}

Received Fuly 25, 1990

\begin{abstract}
Pavlas M., J. Zbořil, J. Petráš, R. Dvořák, V. Jordán: Virulence of Mycobacterium johnei in Experimentally Infected Calves. Acta vet. Brno, 60, 1991: 367 to 373.

Virulence of the culture collection strain CCM 5889 and the field strain $1 / 623$ of Mycobacterium johnei, isolated from cattle showing signs of Johne's disease, was examined by experimental infection in 12 calves. The strain CCM 5889, inoculated intravenously or subcutaneously, did not elicit clinical signs in any of the calves during 30 weeks. All calves reacted in the skin test to avian tuberculin and johnin from the 5 th to the 11 th post-inoculation week. The strain $1 / 623$ killed all 3 calves inoculated intravenously within 3 to 5 weeks after inoculation. The strain was reisolated from altered parenchyma and from lung and mesenterial lymph nodes of all 3 calves and from the small intestinal mucosa of one of them. Also the sensitization potency of the strain 1/623 was higher than that of the strain CCM 5889 and hypersensitivity of johnin persisted 6 months at least. Apart from calves dying after intravenous inoculation, faeces samples were free of mycobacteria over the whole observation period. Antibodies to the CCM 5889 antigen were demonstrated by the indirect haemagglutination test 5 weeks after intravenous inoculation with any of the strains used, and positive titres persisted for 3 months. Subcutaneous inoculation resulted in antibody titres: $1: 64-1: 128$ only if the strain 1/623 was used. All surviving calves were free of mycobacteria (incl. the inoculation site) when sacrificed 6 months after inoculation.
\end{abstract}

Mycobaterium johnei (paratuberculosis), biological properties, sensibilization, pigs, chickens, laboratory animals

Johne's disease is at present a widely distributed bacterial infection of ruminants, causing considerable economic losses above all in large farms with high-yielding animals. Although the aetiology of the disease had been recognized at the end of the past century already, its pathogenesis has not been fully clarified yet and preventive measures and diagnostic methods require continuing attention.

The rise of the disease depends on the age of the animal, virulence of the causal agent, route and intesity of infection and on a number of further factors. It has been generally postulated that young animals are more susceptible. While it was easy to induce the disease in calves (Taylor 1953), adult cattle showed a higher resistance (Bang 1976). Clinical signs developed as late as 5 to 24 months after oral infection (Smythe 1935). Conclusive evidence of infection in experimentally infected animals was shedding of the causal agent in feces. All mycobacterial strains, growing in primary cultures on mycobactin-containing media, which were isolated from free living animals incl. pigeons, were virulent for calves infected intravenously and lesions found upon necropsy were typical of Johne's disease (Thorel et al. 1984).

The most important source of infection are clinically ill animals, which develop overt signs during pregnancy or early lactation in most cases. Johne's disease has been reported more frequently from areas where soils are poor in certain minerals, esp. calcium, and from herds exposed to conditions affecting the general resistance of animals (Jan sen 1948; Doyle 1956). Other out- 
breaks were associated with environmental changes, e.g. changes of housing facilities (Hole 1955). These facts demonstrate that factors responsible for the rise of the clinical forms of Johne's disease have not been elucidated reliably.

The typical profuse diarrhoea, described in cattle as a rule, is absent in some other animal species, e.g. sheep (S e a man et al. 1981; New sholme and Fletcher 1981; Dent 1985). However, massive shedding of Mycobacterium johnei was observed in animals free of clinical signs. Demonstration of larger aggregates of acid-fast mycobacteria in samples of intestinal mucosa, faeces or lymph nodes by the Ziehl-Neelsen's method is usually sufficient for the diagnosis. However, demonstration of the causal agent by culture is considered the most reliable method for the diagnosis of Johne's disease (Foodstad and Gunnarson 1979).

Most authors, investigating the pathology of Johne's disease, state that lymph nodes and parenchymatous organs of affected animals are free of lesions, such as necrosis or caseation. Findings of nodular demarcated tuberculosis-like necrotic lesions in mesenterial lymph nodes were rather exceptional (Weidlich 1954). Epitheloid cells, containing large numbers of acid-fast bacteria with properties typical of $M$. johnei, were found in caseous granulomas (Monotani and Yoshino 1985). Intestinal mucosa and mesenterial lymph nodes are affected most frequently, but lesions were found in other organs, too. In infected goats, lesions with central necroses were present in the liver parenchyma (Morin 1982) and histological alterations were observed in adrenal glands (Rajan et al. 1980) and kidneys and other organs (Hines et al. 1987).

\section{Materials and Methods}

Twelve 2- to 3-month-old calves, with a live weight of $120-130 \mathrm{~kg}$ were used in the examination of virulence of the culture collection strain CCM 5889 (Ptb3) and the field strain 1/623, isolated on the modified Dubos' medium with mycobactin (Smith 1953) and on Stonebrink's egg yolk medium. The strain CCM 5889, used for the production of johnin, propagated well on conventional media without growth promotors.

The examination of the mycobacterial cultures by bioassay was carried out on pullets aged 4 weeks. All 3 birds survived after intramuscular inoculation of $5 \mathrm{mg}$ of a moist culture of the strain CCM 5889. Apart from enlarged spleens with sporadic caseous foci, parenchymatous organs were free of lesions, when the chickens were necropsied 5 month after inoculation. The strain was reisolated from the spleen of 2 chickens. Spleen edema was observed in chickens inoculated intravenously with $1 \mathrm{mg}$ of the racterial mass of the same strain and necropsied 3 months thereafter. The strain was reisolated from the spleen and liver tissue. On the other hand, mice, inoculated intravenously, died within 3 months and the strain was reisolated from the spleen and liver tissue. Abscesses developed at the inoculation of $1 \mathrm{mg}$ of the culture in guinea pigs. Parenchymatous organs were free of lesions and the strain was reisolated from the inoculation site only. No lesions were found in parenchymatous organs of a rabbit 3 months after inoculation of $1 \mathrm{mg}$ of the culture and results of bacteriological examinations were negative, too. These results have demonstrated a very low virulence of the strain CCM 5889 for laboratory animals.

On the other hand, the strain $1 / 623$ showed a higher virulence for chickens, killing them within 4 month after intravenous inoculation of $2 \mathrm{mg}$ of the culture. The chickens were cachectic and showed spleen and liver oedema upon necropsy. The strain was reisolated from the spleen, liver and lung. No chicken died within 6 months after intramuscular inoculation of $5 \mathrm{mg}$ of the culture. Bean-sized muscular degeneration at the inoculation site and slightly enlarged spleens and livers were observed upon necropsy. The strain was reisolated from the inoculation site, and in one of the two chickens, from the spleen and liver tissue.

Shedding of the strain $1 / 623$ was demonstrable in 2 pigs, inoculated orally with $5 \mathrm{mg}$ of the culture 4 weeks after inoculation, and persisted till slaughter 3 months later. Mycobacteria were reisolated from mesenterial and submaxillar lymph nodes of one of them, and from mesenterial lymph nodes and small intestinal mucosa collected from the proximity of the ileocaecal valve of the other one after slaughter. Four pigs were exposed to contact infection by housing them together with the experimentally infected ones. All developed allergy to avian tuberculin and johnin within 1 to 3 months after the beginning of exposure. Gross lesions were found in mesenterial and submaxillar lymph nodes of 1 of them. The strain was reisolated from all samples of altered parts of the lymph nodes.

All calves selected for the experiment were negative in the allergic skin tests performed with mammalian tuberculin (2 $500 \mathrm{TU}$ ), avian tuberculin and johnin (both $1600 \mathrm{TU}$ ). Also negative were the results of the haemagglutination test using purified protein derivatives of Mycobacterium avium and Mycobacterium johnei strain CCM 5889, and serum dilution $1: 8$. 
Suspensions, containing $1 \mathrm{mg}$ culture per $1 \mathrm{ml}$ sterile physiological saline, were prepared from both $M$. johnei strains, using glass beads for homogenization.

Twelve calves were divided into 2 equal groups inoculated with the strains CCM 5889 and 1/623, respectively. Each group was divided into two subgroups, inoculated subcutaneously (in the neck region) and intravenously (vena jugularis), respectively. Each calf received a dose of $0.1 \mathrm{mg}$ of the respective culture per $1 \mathrm{~kg}$ live weight. All calves were examined clinically and skin tests, using avian tuberculin and johnin, and bacteriological examinations of faeces were performed on post-inoculation days 34, 77, 152 and 187. At the same time, blood samples for serological examinations were collected.

Samples of approximately $1 \mathrm{~g}$ of lymph nodes, intestinal mucosa and parenchymatous organs were homogenized in a mortar for the examination by culture. The homogenates were treated with $3.5 \mathrm{ml} 1 \mathrm{M} \mathrm{HCl}$ for 20 minutes and neutralized with $2 \mathrm{ml} 2 \mathrm{M} \mathrm{NaOH}$ if not examined immediately after collection. Samples of intestinal contents and mucosa were decontaminated by $4 \%$ $\mathrm{NaOH}$ and $5 \%$ oxalic acid. In addition to selective media i.e. the modified Dubos' medium with mycobactin (Smith 1953) and a suspension of $M$. phlei in glycerol (as advised by Dr. Stika from the Central Veterinary Institute, Prague) conventional media for mycobacteria were used, too. The cultures were incubated at $37^{\circ} \mathrm{C}$ for 10 to 12 weeks and their growth was checked at two-week intervals.

\section{Results}

Neither intravenous, nor subcutaneous inoculations of the culture collection strain CCM 5889 elicited clinical signs in any of the calves within 30 weeks, but all showed positive reactions to avian tuberculin and johnin between the 5 th and 11th postinoculation week (Table 1). Two thirds of the calves, inoculated intravenously or subcutaneously with the strain CCM 5889, responded to johnin by increases in skin measurements over $3 \mathrm{~mm}$. The highest increase in skin measurements with avian tuberculin was $2.5 \mathrm{~mm}$. A transient increase of hypersen-

Table 1

Dynamics of hypersensitivity to avian tuberculin and johnin in calves inoculated with $0.1 \mathrm{mg}$ of $\mathrm{M}$. johne culture per $1 \mathrm{~kg}$ liveweight

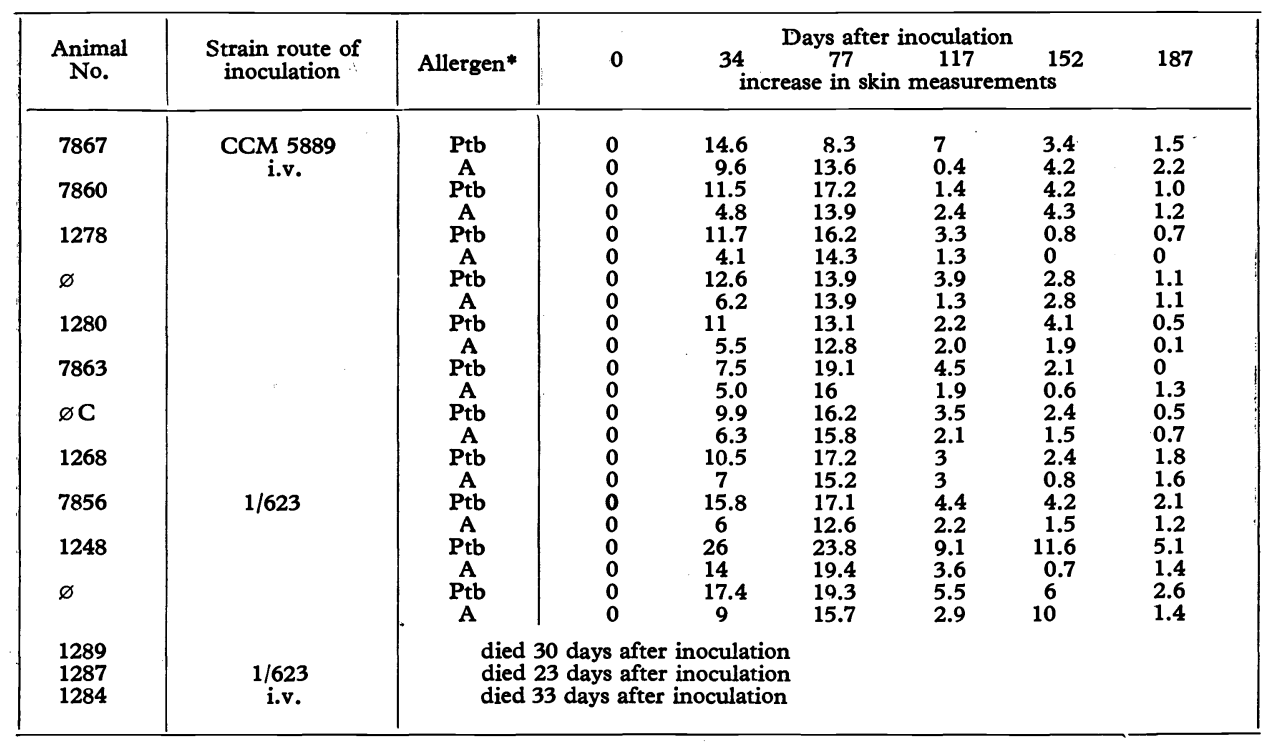

* Ptb = johnin

A $=$ avian tuberculin 
sitivity to both allergens was observed in some animals during the subsequent period, but none of the calves reacted to any of them at the end of the observation period, i. e. 6 month after inoculation.

The virulence of the field strain 1/623 was markedly higher. All 3 calves inoculated intravenously died within 3 to 5 weeks and serious gross lesions were found in the lung upon necropsy. Reisolation of the strain was successfull from the lung parenchyma and corresponding lymph nodes, and, in one calf, from the small intestinal mucosa. A swelling at the inoculation site, reaching its maximum 4 weeks after inoculation, was observed in all calves. The sensitization potency of the strain 1/623 was higher compared with that of CCM 5889. Two and one calf of the group inoculated subcutaneously reacted to johnin 5 and 6 months after inoculation, respectively.

With the exception of animals dying after intravenous inoculation of the strain 1/623, mycobacteria were not detected in faeces, irrespective of the strain used. Haemagglutination tests with the homologous antigen revealed positive titres 5 weeks after inoculation with the strain CCM 5889. The titres persisted till the 4 th post-inoculation month, varying between $1: 64$ and $1: 128$. The calves inoculated intravenously with the strain $1 / 623$ were not examined serologically owing to their early death. Positive haemagglutination titres developed also in calves inoculated with the strain 1/623, but not in those inoculated with the strain CCM 5889. The titres reached their peak values 2 months after inoculation and decreased later to disappear in all animals 5 months after inoculation.

Bacteriological examinations demonstrated the presence of mycobacteria only in calves inoculated intravenously with the strain $1 / 623$. Positive findings were obtained from the lung parenchyma and mesenterial and mediastinal lymph nodes

Table 2

Pathological and bacteriological findings in calves inoculated with $M$. johnei

\begin{tabular}{|c|c|c|c|c|c|c|c|}
\hline \multirow{2}{*}{$\begin{array}{l}\text { Animal } \\
\text { No. }\end{array}$} & \multirow{2}{*}{$\begin{array}{l}\text { Strain inoculation } \\
\text { route }\end{array}$} & \multirow{2}{*}{$\begin{array}{l}\text { Weeks after inoculation } \\
\text { dead slaughtered }\end{array}$} & \multirow{2}{*}{ Lesions } & \multicolumn{4}{|c|}{ Presence of mycobacteria } \\
\hline & & & & $\mathbf{A}$ & $\mathbf{B}$ & C & $\mathbf{D}$ \\
\hline 7867 & - CCM 5889 & 28 & 1 & neg. & neg. & neg. & neg. \\
\hline $\begin{array}{l}7860 \\
1278\end{array}$ & & $\begin{array}{l}29 \\
29\end{array}$ & $\begin{array}{l}2 \\
2\end{array}$ & $\begin{array}{l}\text { neg. } \\
\text { neg. }\end{array}$ & $\begin{array}{l}\text { neg. } \\
\text { neg. }\end{array}$ & $\begin{array}{l}\text { neg. } \\
\text { neg. }\end{array}$ & $\begin{array}{l}\text { neg. } \\
\text { neg. }\end{array}$ \\
\hline 1280 & CCM 5889 & 28 & 3 & neg. & neg. & neg. & neg. \\
\hline $\begin{array}{l}1321 \\
7863\end{array}$ & & $\begin{array}{l}30 \\
30\end{array}$ & $\begin{array}{l}4,5 \\
1,4\end{array}$ & $\begin{array}{l}\text { neg. } \\
\text { neg. }\end{array}$ & $\begin{array}{l}\text { neg. } \\
\text { neg. }\end{array}$ & $\begin{array}{l}\text { neg. } \\
\text { neg. }\end{array}$ & $\begin{array}{l}\text { neg. } \\
\text { neg. }\end{array}$ \\
\hline 1268 & $1 / 623$ & 28 & 1,6 & neg. & neg. & neg. & neg. \\
\hline $\begin{array}{l}7856 \\
1248\end{array}$ & 0.0 & $\begin{array}{l}28 \\
30\end{array}$ & $\begin{array}{l}1,7 \\
8\end{array}$ & $\begin{array}{l}\text { neg. } \\
\text { neg. }\end{array}$ & $\begin{array}{l}\text { neg. } \\
\text { neg. }\end{array}$ & $\begin{array}{l}\text { neg. } \\
\text { neg. }\end{array}$ & $\begin{array}{l}\text { neg. } \\
\text { neg. }\end{array}$ \\
\hline 1289 & $1 / 623$ & 4 & 1,6 & neg. & pos. & pos. & pos. \\
\hline $\begin{array}{l}1287 \\
1204\end{array}$ & & $\begin{array}{l}3 \\
5\end{array}$ & $\begin{array}{l}1,9 \\
10\end{array}$ & $\begin{array}{l}\text { neg. } \\
\text { pos. }\end{array}$ & $\begin{array}{l}\text { pos. } \\
\text { pos. }\end{array}$ & $\begin{array}{l}\text { pos. } \\
\text { pos. }\end{array}$ & $\begin{array}{l}\text { pos. } \\
\text { pos. }\end{array}$ \\
\hline
\end{tabular}

1. Hepatization of apical lung lobes

2. No

3. Pea-sized fibrous lesion at the inoculation site

4. Enlarged mesenterial lymph nodes, thickened ileal mucosa

5. Necrotic foci in the liver

6. Enlarged mediastinal lymph nodes

7. Enlarged lung lymph nodes

8. Enlarged mesenterial lymph nodes, hyperaemic ileal mucosa

9. Hyperaemic ileal mucosa

10. Enlarged and hyperaemic mesenterial lymph nodes, hyperaemic ileal mucosa
*) $\mathbf{A}=$ intestinal mucosa

B $=$ mesenterial lymph nodes $\mathbf{C}=$ lung lymph nodes $\mathrm{D}=$ parenchyma of apical lung 
and, in one calf, from the small intestinal mucosa. The results of bacteriological examination also showed that a complete spontaneous clearance of mycobacteria is possible in infected animals (Table 2).

\section{Discussion}

Our experiments have demonstrated that the virulence of culture collection strains of Mycobacterium johnei tends to be very low. The susceptibility of animals depends largely on the route of infection. Experimental infections of calves with a strain isolated from cattle showing clinical signs of Johne's disease was lethal in all animals infected intravenously. Our pathological and bacteriological findings in the lung, as well as the higher susceptibility of calves to intravenous inoculation, correspond with data published by other authors (Larsen et al. 1977). On the other hand, we did not find tubercles, described by some authors (Weidlich 1954) in any of the experimentally infected calves. The benign course of subcutaneous and intravenous infections with the strain CCM 5889 correlated well with the absence of mycobacteria from faeces. Shedding of the causal agent is considered a helpful indicator of susceptibility (Taylor 1953; Bang 1976).

Swine are another species, which may be susceptible to experimental infection with $M$. johnei. We have demonstrated that lesions in swine are similar to those described by some authors in cattle. Morphological alterations, found in various animal species, are dependent on biological properties of mycobacteria participating on the infection.

Our results have confirmed earlier conclusions of some authors, that properties of Mycobacterium johnei are very similar to those of the members of the Mycobacterium avium complex (Chiodini 1990). Owing to a wide variability of strain isolated from cattle and sheep affected with mycobacterial enteritis, strains with growth and other biological properties differing strictly from those of $M$. avium are isolated occasionally.

\section{Virulence Mycobacterium paratuberculosis pừ experimentální infekci telat}

Při experimentální infekci 12 telat byla ověřena virulence kmenů Mycobacterium paratuberculosis, a to sbírkového kmene CCM 5889 a terénního, izolovaného u skotu s př́znaky paratuberkulózy č. 1/623. Po infekci telat sbírkovým kmenem M. paratuberculosis CCM 5889 se nevyskytly během 30 týdnů u žádného z pokusných zviřat klinické příznaky onemocnění, a to jak při intravenózní, tak podkožní inokulaci. U všech telat byla zjištěna při vnitrokožni aplikaci pozitivní reakce na aviární tuberkulín a paratuberkulín $\mathrm{v}$ období 5-11 týdnů po infekci. Výraznè větší virulence byla zjištěna u terénního kmene $M$. paratuberculosis $1 / 623$, který při intravenózní inokulaci vyvolal uhynutí všech 3 telat v obdobi 3-5 týdnů po infekci. Reizolace inokulačního kmene se podařila ze změněného parenchymu, mízních uzlin plic a mezenteriálních a $u$ jednoho ze trú telat rovněž ze sliznice tenkého střeva. Senzibilizační schopnost terénního kmene $1 / 623$ byla rovněž výraznější ve srovnání s kmenem CCM 5889 a udržovala se na paratuberkulín do 6 měsícủ po infekci. Vyšetřeni trusu bylo u všech zviřat (kromě 3 uhynulých telat) po celou dobu pokusu na mykobaktérie negativní. Při sérologickém vyšetrení zviřat 
pomocí neprímé hemaglutinace byly zjištěny pozitivní titry $s$ antigenem připraveným z kmene CCM 5889 za 5 týdnů po infekci pouze u skupiny telat infikované intravenózně, které se udržovaly do 4 měsíců po nakažení. U telat infikovaných podkožně byly zjištěny pozitivní hemaglutinační titry $1: 64-1: 128$ pouze u skupiny telat infikované kmenem $1 / 623$. Bakteriologické vyšetření telat utracených za 6 měsícủ po infekci bylo u všech zviŕat na mykobaktérie negativní včetně místa inokulace.

\section{Вирулентность Мусоbacterium paratuberculosis при экспериментальной инфекции крүпного рогатого скота}

В ходе экспериментальных инфекций 12 телят проверяли вирулентность штаммов Mycobacterium paratuberculosis, а именно штамма ССМ 5889 и штамма, изолированного у крупного рогатого скота с признаками паратуберкулеза № 1/623. После инфекции телят коллекционным штаммом $M$. paratuberculosis CCM 5889 в течение 30 сүток ни у одного из подопытных животных не были выявлены клинические признаки заболевания, ни при внутривенной, ни при подксжной инокуляции. У всех телят при внутрикожном введении была установлена позитивная реакция на авиарный туберкулин и паратуберкулин в период 5-11 недель после инфекции. Более выразительная вирулентность была установлена у полученного в полевых условиях $M$. paratuberculosis 1-623, вызвавшего при внутривенной инокуляции отход всех 3 телят в период 3-5 недель после инфекции. Реизоляция инокүляционного штамма удалась из измененной паренхимы, лимфатических узлов легких и мезентериальных слоев, у одного из трех телят - из слизистой тонкой кишки. Сенсибилизационная способность штамма 1/623 по сравнению со штаммом ССМ 5889 была также более выразительной и удерживалась по отношению к паратуберкулину до 6 месяцев после инфекции. Исследование кала у всех животных (за исключением 3 погибших телят) в ходе опыта на микобактерии было негативным. В ходе серологических исследований животных с помощью косвенной гемагглютинации были установлены позитивные титры с антигеном, подготовленным из штамма ССМ 5889 через 5 недель после инфекции только у группы телят, инфицированных внутривенно, которые продержались до 4 месяцев после инфекции. У подкожно инфицированных телят были установлены позитивные гемаглютинационные титры 1:64-1:128 только у группы телят, инфицированных штаммом 1/623. Бактериологические исследования на микобактерии у телят, умерщвленных через 6 месяцев после инфекции были негативными, включая место инокуляции.

\section{References}

BANG, B.: Chronische pseudotuberkulöse Darmentzündung beim Rinde. Berl. tierärztl. Wsch., 22, 1976: 759-763

DENT, L. H. R.: Complications in field diagnosis of Johne's disease in sheep. Aust. vet. J., 62, 1985: 171

DOYLE, T. M.: Johne's disease. Vet. Rec., 68, 1956: 869-887. 
FOODSTAD, F. M.-GUNNARSON, E.: Post mortem examination in the diagnosis of Johne's disease in goats. Acta vet. scand., 20, 1979: 157-167

HINES, S. A.-BUERGELT, C. D.-WILSON, J. H.-BLISS, L. E.: Disseminated Mycobacterium paratuberculosis infection in a cow. J. Am. vet. med. Ass,. 190, 1987: 681-683

HOLE, N. M.: The diagnosis of Johne's disease. Control of Johne's disease. Eur. Product Ag., 207, 1955: $91-116$

CHIODINI, R. J.: Characterization of Mycobacterium paratuberculosis and organism of thes Mycobacterium avium complex by restriction polymorphism of the RNA gene region. J. Clin. Microb., 28, 1990: 489-494

JANSEN, J.: Paratuberculosis. J. Am. vet. med. Ass., 112, 1948: 52-54

LARSEN, A. B. - MILLER, J. M.-MERKAL, R. S.: Subcutaneous exposure of calves to Mycobacterium paratuberculosis. Compared with intravenous and oral exposures. Am. J. vet., Res., 38, 1977: 1669-1671

MONOTANI, E. - YOSHINO, T.: Caseous granulomas in bovine paratuberculosis. Jap. J. vet. Sci., 47, 1985: 487-491

MORIN, M.: Johne's disease (paratuberculosis) in goats a report of eight cases in Quebec. Can. vet. J., 23, 2, 1982: $55-58$

NEWSHOLME, S. J.-PLETSCHER, J. H.: A mycobacteriosis in a sheep resembling paratuberculosis (Johne's disease). J. south. Afr. vet. Ass., 52, 2, 1981: 143-145

RAJAN, A. - VALSALA, K.-MARIAMMA, K. I. - NAIR, M. K.: Pathology of the endocrine glands of Johne's disease in goats. Kerala J. vet. Sci., 11, 1980: 166-173

SEAMAN, J. T.-RGARONET, I. A.-DENT, C. H. R.: Johne's disease in sheep. Aust. vet. J., 57, 1981: 102-103

SMITH, H. W.: Modifications of Dubo's media for the cultivation of Mycobacterium johnei. J. path. Bact., 66, 1953: 375-381

SMYTHE, R. H.: The clinical aspects of Johne's disease. Vet. Rec., 15, 1935: 85-86

TAYLOR, A. W.: The experimental infection of cattle with varieties of $M$. johnei isolated from sheep. J. comp. Path. Therap., 63, 1953: 368-373

THOREL, M. F.-PARDON, P.-IRGENS, K.-MARLY, J.-LECHOPIER, P.: Experimental paratuberculosis pathogenicity of mycobactin-dependent mycobacterial strains for calves. Annls Rech. vet., 1 513, 1984: 365-374

WEIDLICH, N.: Beitrag zur Histologie der paratuberkulösen Darmentzündung des Rindes. Mh. Tierheilk., 6, 1954: 226-238 